\title{
Growth and yield performance of garlic varieties under zero-tillage and tillage system
}

\author{
Rahman, M. M., Hossain, M. M., Rahman, M. H., Rahim, M. A. \& Islam, M. T. \\ Department of Horticulture, Bangladesh Agricultural University Mymensingh \\ Author for correspondence: mokter.agr@bau.edu.bd
}

Summary: Bangladesh Agricultural University (BAU) developed four garlic variety viz., BAU Garlic-1; BAU Garlic-2; BAU Garlic-3; and BAU Garlic-4 were tested under two cultivation systems viz., zero-tillage and tillage to find out a suitable variety for zero-tillage system. This study was conducted following randomized complete block design with three replicates. Results showed that planting system had significant influenced on growth, yield contributing traits and bulb yield of garlic. It was also observed that all the studied traits were higher in zero-tillage condition as compared to tillage system. There were significant variations noticed among the garlic varieties on plant growth and yield traits. However, in combination of planting system and variety, it was found that BAU Garlic-3 performed superior on plant growth and bulb yield of garlic under zero-tillage system. From the findings of this study, it can be concluded that BAU Garlic-3 could be useful technology for cultivation of garlic in zero-tillage system.

Rahman, M. M., Hossain, M. M., Rahman, M. H., Rahim, M. A. Islam, M. T. (2020): Growth and yield performance of garlic varieties under zero-tillage and tillage system. International Journal of Horticultural Science 26: 46-54. https://doi.org/10.31421/IJHS/26/2020/6065

Key words: bulb diameter, bulb yield, clove number, dry matter content, garlic, tillage system

\section{Introduction}

Garlic (Allium sativum L.) included in the Alliaceae family. This species is an essential aromatic herbaceous annual spices (Kurian, 1995; Baghalian et al., 2005; Islah, 2010). It is the second most extensively used cultivated Allium crop, next to onion in the world (Purseglove, 1975; Bose \& Som, 1990). Garlic is accepted around the world as an excellent spice for cooking various food items. Garlic consists of amino acid which reduces cholesterol levels in human blood. Moreover, the juicy extract of garlic cloves (containing allicin and related disulfides) reduces cholesterol level in human body (Augusti, 1977). It assists removing waste materials and deadly free radicals from human body (Durak et al., 2004). It is rich in anti-infective properties such as anti-bacterial, antifungal and insecticidal features. In addition, it has anti-cancer properties, lowering of blood sugar and blood lipids as well as it reduces blood platelet aggregation (Agusti, 1990; Jones et al., 2004). It is also cultivated for its beneficial compound allicin (Taucher et al., 1996), this compound is used to combat against diseases (Tucak et al., 2009).

Garlic is grown extensively as a spice crop in Bangladesh, but yield is much lower than in other garlic growing countries in the world. The world average yield of garlic is about $10 \mathrm{t} / \mathrm{ha}$ where China is the largest producer occupying more than $3 / 4$ of the total world production (Wang et al., 2014). In 2013, Bangladesh produced about 224 thousand metric tons of garlic from 105 thousand acres of land with a production of $5.27 \mathrm{t} / \mathrm{ha}$ (BBS, 2014). The demand of garlic consumption is increasing daily with the population of Bangladesh. Therefore, one of the aim is to increase yield of garlic by improving cultivation methods such as appropriate planting system, growing condition, mulching, disease resistant variety and cultural management.
Planting system plays an essential role in the yield features of garlic. Garlic is known to be thermo and photo-sensitive crop and this species are well influenced by growing environmental conditions (Rahim \& Fordham, 1988). Garlic prefers cool weather and grow in a well-drained, moderately clay loam at higher elevation (900 to 1200 meters). In Bangladesh, the growth period of garlic is concentrated in the winter season from November to March. As a result, only early planted crops can utilize full advantages of the cool period. But the farmers of Bangladesh cannot always complete early planting due to climatic limitations and cropping pattern. Therefore, farmers bound to planted garlic cloves lately as a results crops are exposed to increase high temperature before initiation of clove and during the period of growth and development. So, the yield becomes low and sometimes a number of plants are completely failed to initiate bulb.

In Bangladesh, growers are planted garlic after harvest of transplant aman rice as a result planting time become delayed thus resulting reduced bulb yield. To adjust the planting time many of growers in flood affected area are following a new system for garlic production.

After flood farmers are practiced a new technology to produce garlic in the wet land. Recently, it has been reported that garlic growers of 'Chalanbeel' area of North-Western part of Bangladesh planted garlic in the marshy land without any tillage followed by covering with rice debris. In this farming system, farmers are simply dibbled garlic cloves in the muddy land after harvesting of rice. Garlic yield found to be increased in zerotillage system with application of $10 \mathrm{~cm}$ thick water hyacinth mulch (Kabir et al., 2011). Maximum financial benefit can be achieved from zero-tillage system where the production cost was reduced by $33 \%$ as compared to conventional practices of garlic 
production (Pokhrel \& Soni, 2018). In zero-tillage system soil remains covered with crop residues which assist to efficient erosion control and also improve biological activity in the soil. Moreover, this system helps to retain soil moisture and reduce soil compaction and it requires less energy for cultivation (Derpsch et al., 2010). They also noticed that this system reduces nitrous oxide emission by $40-70 \%$. The soil quality index of nontillage soil is significantly higher as compared to conventional tillage (Aziz et al., 2012). Non-tillage farming is highly favorable to soil and water conservation and reduction of production cost. It is potential for sequestering soil organic carbon (Angers et al., 1997; Puget \& Lal, 2005).

The usual practice of garlic production is tillage system where the land is ploughed properly to get a good tilth condition and to maintain soil moisture near field capacity. Therefore, it is necessary to compare farmers practice under tillage and zerotillage system for garlic production. Many researchers have already been done several studies on various issues of zero-tillage garlic at home and abroad (Derpsch et al., 2010; Alam et al., 2010; Kabir et al., 2011; Islam et al., 2015).

In some studies, they have been investigated the growth and yield performances of Bangladesh Agricultural Research Institute (BARI) developed varieties of garlic in zero-tillage condition with and/or without mulch. Meanwhile, Bangladesh Agricultural University (BAU) has developed some promising high yielding garlic varieties for the farmers. It is necessarily important to test those varieties for cultivation in tillage and nontillage systems. The production of garlic can greatly be increased by adopting new high yielding variety and new planting system. There is no such garlic variety developed for zero-tillage cultivation in Bangladesh, therefore, this study was undertaken to investigate the growth and yield performances of BAU released garlic varieties in zero-tillage and tillage systems.

\section{Materials and methods}

\section{Experimental site}

This study was prepared at USDA Alliums' Project field Laboratory, Horticulture Farm, Bangladesh Agricultural University, Mymensingh during November 2014 to March 2015. The site is situated at $24.6^{\circ} \mathrm{N}$ latitude and $90.5^{\circ} \mathrm{E}$ longitude. The elevation of the area is approximately $18 \mathrm{~m}$ from average sea level. The soil type was sandy loam and belongs to the Old Brahmaputra Flood Plain Alluvial Tract of Agro Ecological Zone 9 having non-calcareous soil. The site was a medium high land and $\mathrm{pH}$ of the soil was 6.45 with organic matter content of $0.85 \%$. The site is located under the subtropical monsoon climate, which have high temperature and heavy rainfall between April and September and scanty rainfall during October to March.

\section{Experimental treatments}

The two-factor study comprised with two planting systems viz., $\mathrm{T}_{1}$ : Zero-tillage, $\mathrm{T}_{2}$ : Tillage and four varieties of $\mathrm{BAU}$ released garlic viz., $\mathrm{V}_{1}$ : BAU Garlic-1, $\mathrm{V}_{2}$ : BAU Garlic-2, $\mathrm{V}_{3}$ : BAU Garlic-3, V4: BAU Garlic-4.

\section{Land preparation}

In zero-tillage system $\left(\mathrm{T}_{1}\right)$ only weeds and remaining parts of previous crops were removed from the field. Irrigation and drainage were done around the experimental plots. In case of tillage system $\left(\mathrm{T}_{2}\right)$, the selected experimental plot was ploughed by a power tiller followed by laddering up to a depth of $10 \mathrm{~cm}$ were done until the desired tilth was achieved for planting the clove. The plot received the basal doses of manure and fertilizers.

\section{Design and layout of the experiment}

The experiment was designed in a randomized complete block design with three replications. The experimental land was divided into three blocks. Total number of plots was 24 for this experiment. The size of unit plot was 2 × $0.9 \mathrm{~m}$. The spaces between blocks were $1 \mathrm{~m}$ and between plots was $0.5 \mathrm{~m}$.

\section{Application of manures and fertilizers}

Well decomposed cowdung (10 t/ha) was applied to the experimental field at 15 days before planting cloves. Urea (120 $\mathrm{kg} / \mathrm{ha})$, TSP (90 kg/ha) and MoP (180 kg/ha) were used as source of N, P and K, respectively. Full amount of TSP and 50\% of urea and MoP were applied at planting. The rest of urea and MoP were applied as top dressed in two equal installments at 30 and 60 days after planting.

\section{Planting and other intercultural operations}

Cloves were planted at a depth of $5 \mathrm{~cm}$ and covered with straw which works as a mulch material and helps to conserve soil moisture. One hundred twenty cloves were planted in each unit plot at spacing of $15 \mathrm{~cm}$ x $10 \mathrm{~cm}$. Weeding was done periodically whenever necessary. In case of tillage system, the field was irrigated twice using flood irrigation during the whole period of plant growth. Dithane M 45 at $2 \mathrm{~g} / \mathrm{L}$ of water was sprayed to control garlic thrips. Additionally, Rovral at 2.5 $\mathrm{g} / \mathrm{L}$ of water was applied to prevent purple blotch disease of garlic.

\section{Harvesting and data collection}

Harvesting was done on $25^{\text {th }}$ March 2015 when the plants reached maturity showing the normal sign of drying out of most of the leaves and the top leaves started drying and natural dropping at the neck. Plants were lifted with the help of Nirani. Then the bulbs were exposed to the sun for drying and cleaned to remove all soil particles. Periodical data on plant height and number of leaves were recorded at 10 days intervals up to 80 days after planting (DAP) and rest of parameters were recorded after harvest of crops. Fresh weight of leaves, bulbs, roots, number of roots, cloves, dry weight of leaves, roots, bulbs (after $72 \mathrm{hr}$ oven dried at $70^{\circ} \mathrm{C}$ ) and diameter of bulbs were recorded at harvest. The total yield per hectare was calculated from the yield obtained per plot and presented in $\mathrm{t} / \mathrm{ha}$.

\section{Statistical analysis}

Data were analyzed by using MSTAT C statistical package program. Treatments means were calculated and ANOVA was performed by $F$ tests. The significant difference between treatment mean pairs was evaluated by least significant difference (LSD) test at $1 \%$ level of probability (Gomez and Gomez, 1984). 


\section{Results}

\section{Plant height}

Plant height was recorded at 10, 20, 30, 40, 50, 60, 70 and 80 days after planting (DAP). It was observed that plant height was significantly different in two planting systems from 30 to 80 DAP. At 80 DAP, zero-tillage system produced the higher plant height $(51.27 \mathrm{~cm})$ where tillage system produced the lower plant height $(46.31 \mathrm{~cm})$ (Figure 1/a). BAU Garlic-3 produced the highest plant height $(54.27 \mathrm{~cm})$ at 80 DAP. On the other hand, the lowest plant height $(44.79 \mathrm{~cm})$ was found in BAU Garlic-4 (Figure 1/b). The combined effects of planting system and variety at different growth stage were significant. The longest plant height $(57.25 \mathrm{~cm})$ was recorded in the treatment combination of BAU Garlic-3 with zero-tillage at 80 DAP, while the shortest plant height $(43.26 \mathrm{~cm})$ was observed in tillage with BAU Garlic-4 (Table 1).

\section{Leaf number}

Leaf number was significantly influenced by planting systems. It was observed that zero-tillage produced the higher leaf number $(6.74)$ and the lower leaf number $(6.43 \mathrm{~cm})$ was found in tillage system (Figure 2/a). The four garlic varieties were significant in respect of leaf number per plant at different days after planting (DAP). It was found that leaf number increased as plant growth progressed. At 80 DAP, BAU Garlic-3 (54.27) produced maximum leaves followed by BAU Garlic-1 (50.39) and minimum leaves (44.79) produced by BAU Garlic-4 (Figure 2/b). The combined effects of planting system and variety were significant in respect of leaf number of plants. At 80 DAP, the maximum number of leaves per plant was recorded in the treatment combination of BAU garlic-3 with zero-tillage (7.00) and the minimum number of leaves per plant was recorded from BAU garlic-4 with tillage (5.75) (Table 2).

\section{Fresh weight of leaves}

Fresh weight of leaves was influenced by the planting system. The higher fresh weight of leaves $(12.34 \mathrm{~g} / \mathrm{plant})$ was recorded in zero-tillage system and the lower (12.06 g/plant) was recorded in tillage system (Table 3). A significant variation in respect of fresh weight of leaves was found due to the effect of variety. The highest fresh weight of leaves was found in BAU Garlic-3 (14.19 g/plant) and the lowest was recorded in BAU Garlic-4 (11.12 g/plant) (Table 4). The combination of planting system and variety significantly influenced fresh weight of leaves. The highest fresh weight of leaves was found on BAU Garlic-3 with zero-tillage and the lowest was recorded in the treatment combination of in BAU Garlic-4 with tillage system (10.95 g) (Table 5).

\section{Dry weight of leaves}

The effects of planting system on leaf dry weight were significant. A higher leaf dry weight was assessed in zerotillage (1.59 g/plant) compared to tillage system ( $1.56 \mathrm{~g} / \mathrm{plant})$ (Table 3). The effects of variety on leaf dry weight were significant. The highest leaf dry weight was observed in BAU Garlic-3 (1.76 g/plant) followed by BAU Garlic-1 (1.53 $\mathrm{g} /$ plant), BAU Garlic-2 (1.52 g/plant) and the lowest BAU Garlic 4 (1.47 g/plant) (Table 4). Results showed that leaf dry weight was higher in the treatment combination of zero-tillage and BAU Garlic-3 (1.80 g/plant). On the other hand, the lowest leaf dry weight was recorded from tillage and Garlic- 4 (1.46g/plant) (Table 5).

\section{Number of roots}

The effects of planting system on number of roots per bulb were significant. Root number was greater in zero-tillage (50.35/plant) compared to tillage system (47.18/plant) (Table 3). The effects of variety on number of roots per bulb were significant. The highest root number was found in BAU Garlic3 (54.80/plant) followed by BAU Garlic-1 (51.04/plant), BAU Garlic-2 (46.94/plant) and the lowest number of roots recorded in BAU Garlic-4 (42.28/plant) (Table 4). The roots number per bulb was also significantly influenced by the combined effects of planting system and variety. Results showed that the highest number of roots was recorded in the treatment combination of BAU Garlic-3 with zero-tillage (57.20/plant) and the lowest number of roots was recorded from BAU Garlic-4 with tillage system (41.12/plant) (Table 5)

\section{Fresh weight of roots}

Planting system significantly influenced fresh weight of roots. A higher fresh weight of roots $(0.83 \mathrm{~g} / \mathrm{plant})$ was found in zero-tillage system compared to tillage system $(0.80 \mathrm{~g} / \mathrm{plant})$ (Table 3). There was significant effect on fresh weight of roots. The highest fresh weight of roots was found in BAU Garlic-3 $(0.89 \mathrm{~g} /$ plant $)$ and the lowest was recorded in BAU Garlic-4 (0.73g/plant) (Table 4). The combination of planting system and variety significantly influenced fresh weight of roots. The highest fresh weight of roots was found on BAU Garlic-3 with zero-tillage $(0.90 \mathrm{~g} /$ plant $)$ and the lowest was recorded in the treatment combination of in BAU Garlic-4 with tillage system (0.71 g/plant) (Table 5).

\section{Dry weight of roots}

Planting system significantly affected root dry weight. The higher root dry weight was recorded in zero-tillage $(0.51 \mathrm{~g} / \mathrm{plant})$ compared to tillage $(0.50 \mathrm{~g} / \mathrm{plant})$ (Table 3). Root dry weight varied significantly based on variety of garlic. The highest root dry weight was measured in BAU Garlic-3 $(0.58 \mathrm{~g} / \mathrm{plant})$ and the lowest in BAU Garlic-4 (0.45g/plant) (Table 4). Planting system and variety significantly influenced root dry weight. Results showed that the root dry weight was higher in the treatment combination of zero-tillage with BAU Garlic-3 (0.59g/plant). The lower root dry weight was observed in the treatment combination of tillage system and BAU Garlic-4 (0.44g/plant) (Table 5).

\section{Diameter of bulb}

The effects of planting system on bulb diameter were significant. Bulb diameter was higher in zero-tillage $(3.70 \mathrm{~cm})$ compared to tillage $(3.65 \mathrm{~cm})$ (Table 6). Bulb diameter was statistically significant due to different varieties. The bulb diameter was higher in BAU Garlic-3 $(3.93 \mathrm{~cm})$ and lower in BAU Garlic-4 $(3.54 \mathrm{~cm})$ (Table 7). 

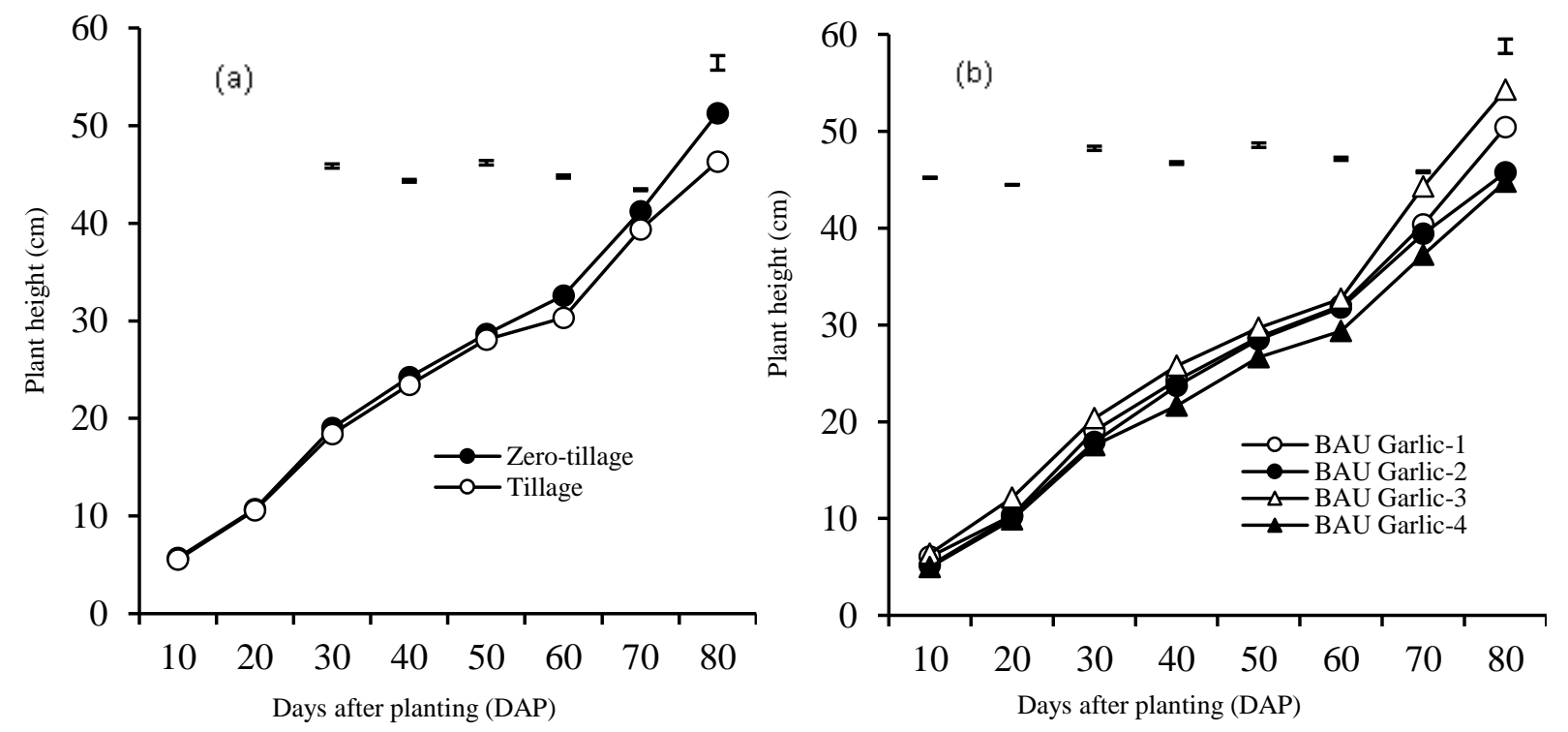

Figure 1. Effects of planting system (a) and variety (b) on plant height of garlic at different days after planting. Vertical bars indicate LSD at $1 \%$ level of significance.
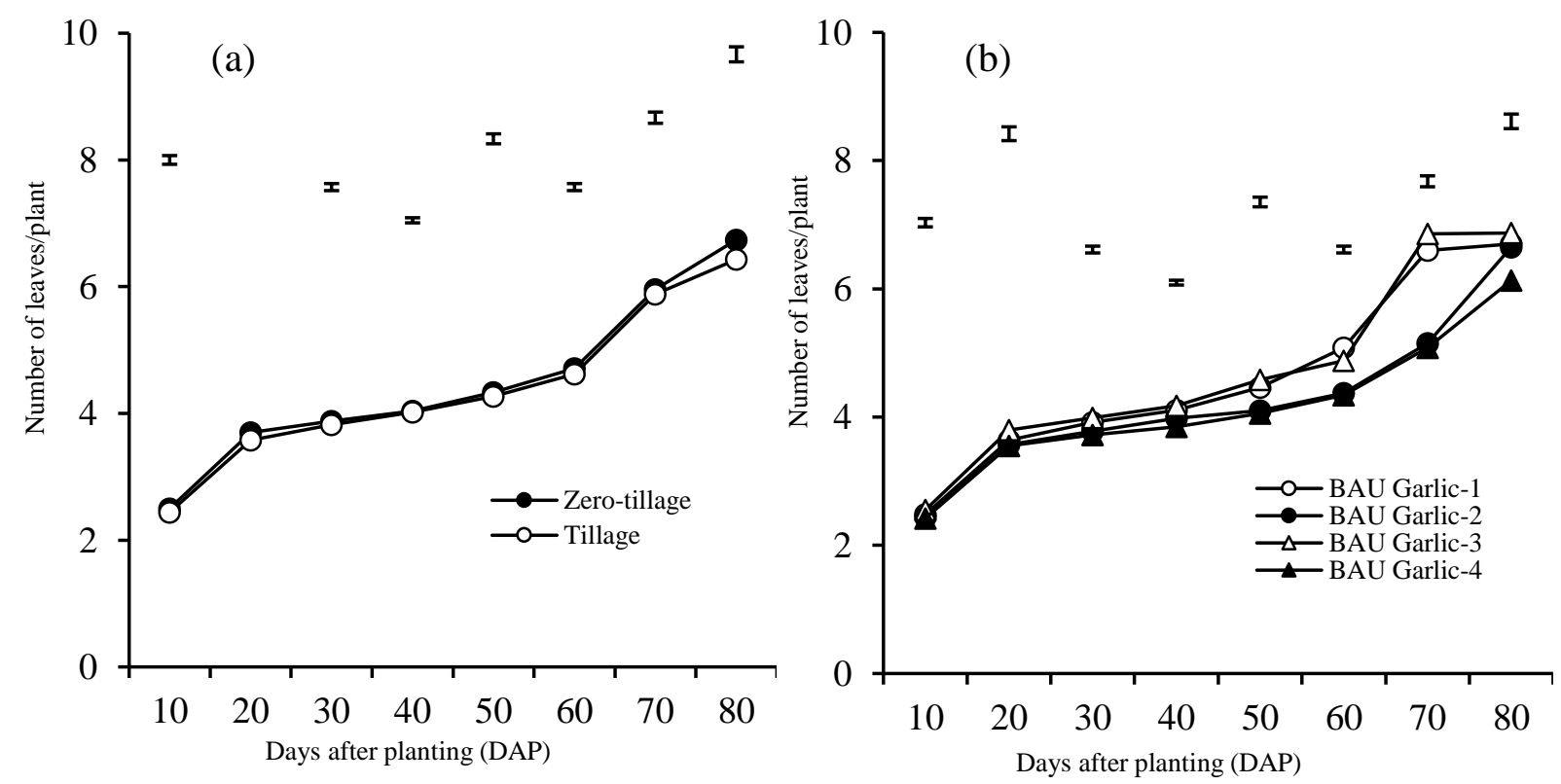

Figure 2. Effects of planting system (a) and variety (b) on number of leaves of garlic at different days after planting. Vertical bars indicate LSD at $1 \%$ level of significance.

Table 1. Combined effects of planting system and variety on plant height of garlic at different days after planting (DAP).

\begin{tabular}{|c|c|c|c|c|c|c|c|c|c|}
\hline \multirow{2}{*}{\multicolumn{2}{|c|}{ Treatment combinations }} & \multicolumn{8}{|c|}{ Plant height $(\mathrm{cm})$ at DAP } \\
\hline & & \multirow{2}{*}{$\frac{10}{6.10}$} & \multirow{2}{*}{$\begin{array}{c}\frac{20}{10.39} \\
\end{array}$} & \multirow{2}{*}{$\begin{array}{c}30 \\
19.13\end{array}$} & \multirow{2}{*}{$\frac{40}{24.39}$} & \multirow{2}{*}{$\begin{array}{c}50 \\
29.31\end{array}$} & \multirow{2}{*}{$\frac{60}{33.53}$} & \multirow{2}{*}{$\begin{array}{c}70 \\
41.12\end{array}$} & \multirow{2}{*}{$\begin{array}{c}80 \\
53.29\end{array}$} \\
\hline & BAU Garlic-1 & & & & & & & & \\
\hline$\stackrel{\Xi}{\Xi}$ & BAU Garlic-2 & 5.30 & 10.21 & 18.43 & 24.22 & 29.01 & 33.45 & 40.39 & 48.23 \\
\hline$\stackrel{\dot{0}}{0}$ & BAU Garlic-3 & 6.50 & 12.23 & 20.50 & 26.07 & 30.15 & 34.20 & 45.25 & 57.25 \\
\hline & BAU Garlic-4 & 5.00 & 9.95 & 18.10 & 22.19 & 26.26 & 29.12 & 38.21 & 46.31 \\
\hline \multirow{4}{*}{$\begin{array}{l}\stackrel{\Xi}{\infty} \\
\stackrel{\Xi}{\Xi} \\
\stackrel{\Xi}{\Xi}\end{array}$} & BAU Garlic-1 & 6.01 & 10.25 & 19.01 & 24.18 & 28.13 & 30.43 & 39.59 & 47.49 \\
\hline & BAU Garlic-2 & 5.00 & 10.15 & 17.35 & 23.13 & 27.93 & 30.09 & 38.36 & 43.21 \\
\hline & BAU Garlic-3 & 6.23 & 12.05 & 20.22 & 25.45 & 29.24 & 31.19 & 43.29 & 51.28 \\
\hline & BAU Garlic-4 & 4.95 & 9.87 & 17.05 & 21.10 & 27.05 & 29.55 & 36.23 & 43.26 \\
\hline \multicolumn{2}{|c|}{$\mathrm{LSD}_{0.01}$} & 0.17 & 0.07 & 0.58 & 0.37 & 0.62 & 0.43 & 0.25 & 1.99 \\
\hline \multicolumn{2}{|c|}{ Level of significance } & $* *$ & $* *$ & $* *$ & $* *$ & $* *$ & $* *$ & $* *$ & *** \\
\hline
\end{tabular}

** indicates significance at $1 \%$ level of probability 
Table 2. Combined effects of planting system and variety on number of leaves of garlic at different days after planting (DAP)

\begin{tabular}{|c|c|c|c|c|c|c|c|c|c|}
\hline \multirow{2}{*}{\multicolumn{2}{|c|}{ Treatment combinations }} & \multicolumn{8}{|c|}{ Number of leaves/plant at DAP } \\
\hline & & \multirow{2}{*}{$\begin{array}{c}10 \\
2.50\end{array}$} & \multirow{2}{*}{$\begin{array}{c}20 \\
3.71\end{array}$} & \multirow{2}{*}{$\frac{30}{3.95}$} & \multirow{2}{*}{$\begin{array}{c}40 \\
4.12\end{array}$} & \multirow{2}{*}{$\begin{array}{c}50 \\
4.50\end{array}$} & \multirow{2}{*}{$\begin{array}{c}60 \\
5.15\end{array}$} & \multirow{2}{*}{$\begin{array}{c}70 \\
6.65\end{array}$} & \multirow{2}{*}{$\begin{array}{c}80 \\
6.75\end{array}$} \\
\hline \multirow{4}{*}{ 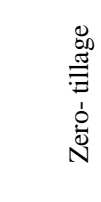 } & BAU Garlic-1 & & & & & & & & \\
\hline & BAU Garlic-2 & 2.47 & 3.62 & 3.83 & 4.00 & 4.13 & 4.40 & 5.19 & 6.69 \\
\hline & BAU Garlic-3 & 2.60 & 3.85 & 4.00 & 4.21 & 4.60 & 4.90 & 6.88 & 7.00 \\
\hline & BAU Garlic-4 & 2.43 & 3.60 & 3.75 & 3.82 & 4.09 & 4.38 & 5.13 & 6.50 \\
\hline \multirow{4}{*}{ 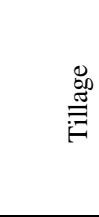 } & BAU Garlic-1 & 2.45 & 3.56 & 3.89 & 4.10 & 4.41 & 5.00 & 6.55 & 6.65 \\
\hline & BAU Garlic-2 & 2.41 & 3.52 & 3.73 & 3.95 & 4.07 & 4.33 & 5.11 & 6.60 \\
\hline & BAU Garlic-3 & 2.50 & 3.75 & 3.98 & 4.15 & 4.56 & 4.85 & 6.83 & 6.73 \\
\hline & BAU Garlic-4 & 2.40 & 3.50 & 3.68 & 3.88 & 4.02 & 4.29 & 5.02 & 5.75 \\
\hline \multicolumn{2}{|l|}{$\mathrm{LSD}_{0.01}$} & 0.13 & 0.21 & 0.10 & 0.07 & 0.15 & 0.10 & 0.17 & 0.23 \\
\hline \multicolumn{2}{|c|}{ Level of significance } & $* *$ & $* *$ & $* *$ & ** & $* *$ & $* *$ & $* *$ & $* *$ \\
\hline
\end{tabular}

** indicates significance at $1 \%$ level of probability

Table 3. Main effects of planting system on fresh weight, dry weight of leaves, number of roots, fresh weight and dry weight of roots.

\begin{tabular}{|l|c|c|c|c|c|}
\hline \multirow{2}{*}{ Planting system } & \multicolumn{2}{|c|}{ Weight of leaves (g/plant) } & \multicolumn{2}{|c|}{ Weight of roots (g/plant) } \\
\cline { 2 - 3 } \cline { 5 - 6 } & Fresh & Dry & & Fresh & Dry \\
\hline Zero-tillage & 12.34 & 1.59 & 50.35 & 0.83 & 0.51 \\
\hline Tillage & 12.06 & 1.56 & 47.18 & 0.09 & 0.50 \\
\hline LSD $_{0.01}$ & 0.05 & 0.03 & 0.32 & $* *$ & $* 05$ \\
\hline Level of significance & $* *$ & $* *$ & $* *$ & $* *$ \\
\hline
\end{tabular}

** indicates significance at $1 \%$ level of probability

Table 4. Main effects of different variety on fresh weight, dry weight of leaves, number of roots, fresh weight and dry weight of roots.

\begin{tabular}{|c|c|c|c|c|c|}
\hline \multirow{2}{*}{ Variety } & \multicolumn{2}{|c|}{ Weight of leaves (g/plant) } & \multirow{2}{*}{$\begin{array}{l}\text { Number of } \\
\text { roots/ plant }\end{array}$} & \multicolumn{2}{|c|}{ Weight of roots (g/bulb) } \\
\hline & Fresh & Dry & & Fresh & Dry \\
\hline BAU Garlic-1 & 12.15 & 1.55 & 51.04 & 0.84 & 0.52 \\
\hline BAU Garlic-2 & 11.35 & 1.52 & 46.94 & 0.81 & 0.48 \\
\hline BAU Garlic-3 & 14.19 & 1.76 & 54.80 & 0.89 & 0.58 \\
\hline BAU Garlic-4 & 11.12 & 1.47 & 42.28 & 0.73 & 0.45 \\
\hline $\mathrm{LSD}_{0.01}$ & 0.07 & 0.05 & 0.45 & 0.13 & 0.07 \\
\hline Level of significance & $* *$ & $* *$ & $* *$ & $* *$ & $* *$ \\
\hline
\end{tabular}

** indicates significance at $1 \%$ level of probability

Table 5. Combined effects of planting system and variety on fresh weight, dry weight of leaves, number of roots, fresh weight and dry weight of roots.

\begin{tabular}{|c|c|c|c|c|c|c|}
\hline \multirow{2}{*}{\multicolumn{2}{|c|}{ Treatment combination }} & \multicolumn{2}{|c|}{ Weight of leaves (g/plant) } & \multirow{3}{*}{$\begin{array}{c}\text { Number of roots/plant } \\
52.57 \\
\end{array}$} & \multicolumn{2}{|c|}{ Weight of roots (g/plant) } \\
\hline & & \multirow{2}{*}{$\begin{array}{l}\text { Fresh } \\
12.30 \\
\end{array}$} & \multirow{2}{*}{$\begin{array}{l}\text { Dry } \\
1.56 \\
\end{array}$} & & \multirow{2}{*}{$\begin{array}{c}\text { Fresh } \\
0.85 \\
\end{array}$} & \multirow{2}{*}{$\begin{array}{c}\text { Dry } \\
0.52 \\
\end{array}$} \\
\hline & BAU Garlic-1 & & & & & \\
\hline$\stackrel{\varpi}{\Xi}$ & BAU Garlic-2 & 11.50 & 1.52 & 48.19 & 0.81 & 0.48 \\
\hline ’’ & BAU Garlic-3 & 14.28 & 1.80 & 57.2 & 0.90 & 0.59 \\
\hline & BAU Garlic-4 & 11.29 & 1.48 & 43.44 & 0.75 & 0.46 \\
\hline \multirow{4}{*}{ 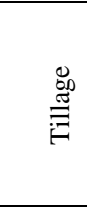 } & BAU Garlic-1 & 12.00 & 1.54 & 49.5 & 0.82 & 0.51 \\
\hline & BAU Garlic-2 & 11.20 & 1.51 & 45.69 & 0.80 & 0.47 \\
\hline & BAU Garlic-3 & 14.10 & 1.71 & 52.40 & 0.87 & 0.56 \\
\hline & BAU Garlic-4 & 10.95 & 1.46 & 41.12 & 0.71 & 0.44 \\
\hline \multicolumn{2}{|c|}{$\mathrm{LSD}_{0.01}$} & 0.10 & 0.07 & 0.63 & 0.18 & 0.10 \\
\hline \multicolumn{2}{|c|}{ Level of significance } & $* *$ & $* *$ & $* *$ & $* *$ & $* *$ \\
\hline
\end{tabular}

** indicates significance at $1 \%$ level of probability 
Table 6. Main effects of planting system on diameter of bulb, number of cloves/bulbs, fresh weight, dry weight and yield of bulb.

\begin{tabular}{|l|c|c|c|c|c|}
\hline \multirow{2}{*}{ Planting system } & \multirow{2}{*}{$\begin{array}{c}\text { Diameter of bulb } \\
(\mathrm{cm})\end{array}$} & \multirow{2}{*}{$\begin{array}{c}\text { Number of } \\
\text { cloves/bulb }\end{array}$} & \multicolumn{2}{c|}{ Weight of bulbs (g/plant) } & \multirow{2}{*}{ Yield of bulb (t/ha) } \\
\cline { 4 - 6 } & 3.70 & 20.93 & 13.78 & 2.90 & 8.27 \\
\hline Zero-tillage & 3.65 & 19.95 & 13.30 & 2.72 & 7.98 \\
\hline Tillage & 0.03 & 0.50 & 0.23 & 0.07 & 0.12 \\
\hline LSD $_{0.01}$ & $* *$ & $* *$ & $* *$ & $* *$ & $* *$ \\
\hline Level of significance & & $* *$ & & \\
\hline
\end{tabular}

** indicates significance at $1 \%$ level of probability

Table 7. Main effects of different variety on diameter of bulb, number of cloves/bulb, fresh weight, dry weight and yield of bulb.

\begin{tabular}{|c|c|c|c|c|c|}
\hline \multirow{2}{*}{ Variety } & \multirow{2}{*}{ Diameter of bulb $(\mathrm{cm})$} & \multirow{2}{*}{$\begin{array}{l}\text { Number of } \\
\text { cloves/bulb }\end{array}$} & \multicolumn{2}{|c|}{ Weight of bulb (g/plant) } & \multirow{2}{*}{ Yield of bulb (t/ha) } \\
\hline & & & Fresh & Dry & \\
\hline BAU Garlic-1 & 3.62 & 19.68 & 13.37 & 3.06 & 8.02 \\
\hline BAU Garlic-2 & 3.61 & 18.15 & 13.05 & 2.94 & 7.83 \\
\hline BAU Garlic-3 & 3.93 & 26.28 & 14.97 & 3.82 & 8.98 \\
\hline BAU Garlic-4 & 3.54 & 17.65 & 12.77 & 1.42 & 7.66 \\
\hline $\mathrm{LSD}_{0.01}$ & 0.04 & 0.71 & 0.32 & 0.10 & 0.17 \\
\hline Level of significance & $* *$ & $* *$ & $* *$ & $* *$ & $* *$ \\
\hline
\end{tabular}

** indicates significance at $1 \%$ level of probability

Table 8. Combined effects of planting system and variety on diameter of bulb, number of cloves/bulb, fresh and dry weight of bulb.

\begin{tabular}{|c|c|c|c|c|c|}
\hline \multirow{2}{*}{\multicolumn{2}{|c|}{ Treatment combinations }} & \multirow{3}{*}{$\frac{\text { Diameter of bulb }(\mathrm{cm})}{3.65}$} & \multirow{3}{*}{$\begin{array}{c}\text { Number of cloves/bulb } \\
20.10\end{array}$} & \multicolumn{2}{|c|}{ Weight of bulb (g/plant) } \\
\hline & & & & \multirow{2}{*}{$\frac{\text { Fresh }}{13.90}$} & \multirow{2}{*}{$\frac{\text { Dry }}{3.12}$} \\
\hline \multirow{4}{*}{ 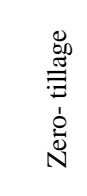 } & BAU Garlic-1 & & & & \\
\hline & BAU Garlic-2 & 3.62 & 18.20 & 13.10 & 2.99 \\
\hline & BAU Garlic-3 & 3.95 & 27.40 & 15.23 & 3.89 \\
\hline & BAU Garlic-4 & 3.56 & 18.00 & 12.87 & 1.59 \\
\hline \multirow{4}{*}{$\underset{ت}{\stackrel{\mathscr{\Xi}}{\Xi}}$} & BAU Garlic-1 & 3.58 & 19.25 & 12.83 & 3.00 \\
\hline & BAU Garlic-2 & 3.60 & 18.10 & 13.00 & 2.88 \\
\hline & BAU Garlic-3 & 3.91 & 25.15 & 14.71 & 3.75 \\
\hline & BAU Garlic-4 & 3.52 & 17.29 & 12.66 & 1.25 \\
\hline \multicolumn{2}{|c|}{$\mathrm{LSD}_{0.01}$} & 0.06 & 1.00 & 0.46 & 0.15 \\
\hline \multicolumn{2}{|c|}{ Level of significance } & $* *$ & $* *$ & $* *$ & $* *$ \\
\hline
\end{tabular}

** indicates significance at $1 \%$ level of probability

The combined effects of planting system and variety on bulb diameter were insignificant. The highest bulb diameter was recorded in the treatment combination of BAU Garlic-3 with zero-tillage $(3.95 \mathrm{~cm})$ and the lowest from BAU Garlic-4 with tillage system $(3.52 \mathrm{~cm})($ Table 8$)$.

\section{Number of cloves}

The effects of planting system on number of cloves per bulb were significant. The cloves number was greater in zero-tillage (20.93/bulb) compared to tillage (19.95/bulb) (Table 6). Number of cloves per bulb varied significantly due to different varieties. BAU Garlic 3 gave the highest number of cloves per bulb (26.28) than BAU Garlic-1, BAU Garlic-2 and BAU Garlic-4 (Table 7). The cloves number per bulb was significantly influenced by the combined effects of planting system and variety. Results revealed the highest number of cloves was recorded in the treatment combination of BAU Garlic-3 with zero-tillage (27.40/bulb) and the lowest from BAU Garlic-4 with tillage (17.29/bulb) (Table 8).

\section{Fresh weight of bulb}

The effects of planting system on fresh weight of bulb were significant. The higher bulb weight was observed in zero-tillage (13.78 g/plant) compared to tillage $(13.30 \mathrm{~g} / \mathrm{plant})$ (Table 6). The effects of variety on fresh bulb weight were significant. The higher bulb weight was observed in BAU Garlic-3 (14.97 g/plant) compared to BAU Garlic-1, BAU Garlic-2 and BAU Garlic-4 (Table 7). Bulb weight was significantly influenced by the combined effects of planting system and variety. The highest bulb weight was recorded in the treatment combination of BAU Garlic-3 with zero-tillage (15.23 g/plant) and the lowest was recorded in BAU Garlic-4 with tillage (12.66 g/plant) (Table 8).

\section{Dry weight of bulb}

The effects of planting system on dry weight of bulb were significant. The higher bulb weight was observed in zero-tillage ( $2.89 \mathrm{~g} /$ plant) compared to tillage $(2.72 \mathrm{~g} / \mathrm{plant})$ (Table 6). The effects of variety on dry weight of bulb were significant. The 
higher dry weight of bulb was observed in BAU Garlic-3 (3.82 g/plant) compared to BAU Garlic-1, BAU Garlic-2 and BAU Garlic-4 (Table 7). Bulb weight was significantly influenced by the combined effects of planting system and variety. Results revealed that the highest bulb weight was recorded in the treatment combination of BAU Garlic-3 with zero-tillage (3.89 $\mathrm{g} / \mathrm{plant})$. On the other hand, the lowest bulb weight was recorded in the treatment combination of BAU Garlic- 4 with tillage $(1.25$ g/plant) (Table 8).

\section{Yield of bulb}

The effects of planting system on bulb yield were significant. The higher bulb yield was observed in zero-tillage $(8.27 \mathrm{t} / \mathrm{ha})$ compared to tillage (7.98 t/ha) (Table 6). Significant variation in yield was found due to different varieties. The highest yield was obtained from the variety BAU Garlic-3 (8.98 t/ha) followed by BAU Garlic-1 (8.02 t/ha), BAU Garlic-2 (7.83 t/ha) and the lowest from BAU Garlic-4 (7.66 t/ha) (Table 7). Bulb yield was significantly influenced by the combined effects of planting system and variety. The highest bulb yield was recorded in the treatment combination of BAU Garlic-3 with zero-tillage (9.14 $\mathrm{t} / \mathrm{ha}$ ). On the other hand, the lowest bulb yield was recorded in the treatment combination of BAU Garlic-4 with tillage system (7.6 t/ha) (Figure 3).

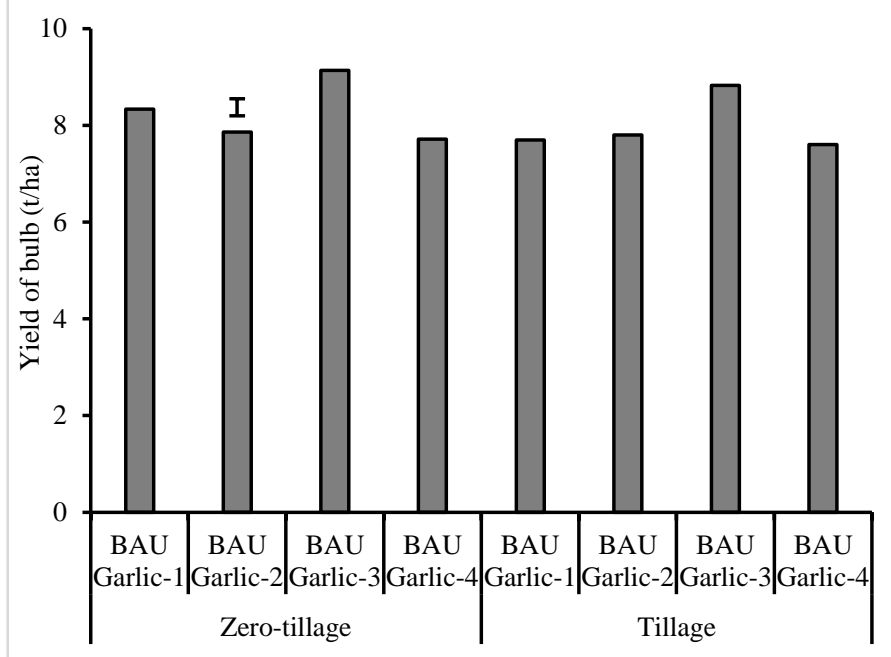

Figure 3. Combined effects of planting system and variety on yield of bulb. Vertical bar indicates LSD at $1 \%$ level of significance.

\section{Discussion}

This study was conducted to select a suitable garlic variety for cultivation in zero-tillage system particularly in low land area where farmers can plant garlic immediate after ending flood. Four garlic varieties were tested in two planting systems to investigate plant growth and bulb yield performance of garlic. In this study we observed plant height, number of leaves, fresh weight, dry weight of leaves, number of roots, diameter of bulb, number of cloves, fresh and dry weight of bulbs and even yield of bulb were higher in zero-tillage system compared to tillage system.

In zero-tillage system, seeds/bulbs are planted directly into untilled soil which contains previous crop residues. This system minimize soil disturbance and allow crop residues to remain on the soil. Soil-arthropod and earthworm densities remain higher in zero or no-tillage system than conventional tillage system (House \& Parmelee, 1985), which helps in decomposition processes of crop residues in the field. Zero-tillage system is becoming popular to the farmers as it reduces production cost significantly as compared to conventional system (De Vita et al., 2007). Soil moisture content remains higher in no-tillage condition along with sufficient organic matter enhance the crop growth and yield.

In zero-tillage system straw mulch was used after planting of cloves which help to conserved soil moisture as well as suppressed weed infestation therefore vegetative growth of plant was improved. Zero-tillage system helps to increase water and fertilizer use efficiency of crop as a results yield increase as compared to tillage condition (Triplett Jr \& Dick, 2008). Zerotillage with mulch using water hyacinth (Kabir et al., 2011) and rice straw (Islam et al., 2015) significantly retained soil moisture and suppressed weed growth which enhanced crop growth and development (Karaye \& Yakubu, 2006). Jamil et al. (2005) reported that straw mulch increased yield and yield contributing traits of garlic and they recommended straw much for garlic production. It is reported that no-tillage system enhances population of beneficial fungi (Arbuscular mycorrhiza) in land which maximizing benefits to crop thus improve crop yield (Kabir, 2005).

In this investigation we noticed that growth and yield performance of garlic were noticeable under zero-tillage system. In response to growth and bulb yield, BAU Garlic-3 performed better among the tested garlic varieties. Bulb yield of garlic can be varied depending on variety, soil types, planting spacing and management practices (Poldma et al., 2005). We noticed that BAU Garlic-3 produced maximum yield (9.14 t/ha) under zerotillage condition as compared to other varieties.

The possible speculation of such result is that the BAU Garlic-3 produced highest plant height and maximum number of leaves which helps in higher photosynthetic activity of plants that contribute to improved bulb size thus ultimately increased the yield. Abdel-Razzak et al. (2013) reported that the variation in number of cloves per bulb as well as yield might be due to the variations among garlic variety and their ability for exploiting environmental factors specially light, carbon dioxide, water, atmospheric humidity, nutrients. Kabir et al. (2013) stated that the garlic bulbs from the zero-tillage showed the highest storage ability resulting in the lowest weight loss.

\section{Conclusions}

The effects of planting system and garlic variety on morphological characters such as plant height and number of leaves per plant, fresh weight of leaves, root dry weight, yield attributing traits such as bulb diameter and number of cloves per bulb and bulb yield was significant. Initial soil moisture content was higher in zero-tillage system than the tillage system before the planting of garlic. Furthermore, zero-tillage conserved soil moisture during the entire growth period of crop. Available moisture at the root zone enhanced vegetative growth and ultimately improved yield in the zero-tillage system. Among the varieties, BAU Garlic-3 performed better in respect of growth and yield contributing traits and gave higher bulb yield. In combined of BAU Garlic-3 with zero-tillage showed better performances than other varieties of garlic. It is summarized that zero-tillage could be useful technology to achieve maximum growth and yield of garlic. 


\section{References}

Abdel-Razzak, H. S., El-Sharkawy, G. A. (2013): Effect of biofertilizer and humic acid applications on growth, yield, quality and storability of two garlic (Allium sativum L.) cultivars. Asian Journal of Crop Science 5:48-64.

Agusti, K. T. (1990): Therapeutic and medicinal values of onions and garlic. p: 99-104. In Brewster, J. L and Rabinowitvh, H. D. eds) Onions and Allied Crops. V. 3. CRC Press, Inc; 1990.

Alam, M. S., Rahim, M. A., Simon, P. W. (2010): Performance evaluation of garlic germplasms under dry land condition. Journal of Agroforestry Systems and Environmental Quality 3 (2): 43-45.

Alam, M. S., Rahim, M. A., Simon, P. W. (2010): Standardization of production technology for garlic under dry and wet land conditions. Journal of Agroforestry and Environment 3(2):5-8.

Angers, D. A., Bolinder, M. A., Carter, M. R., Gregorich, E. G., Drury, C. F., Liang, B. C., Voroney, R. P., Simard, R. R., Donald, R. G., Beyaert, R. P., Martel, J. (1997): Impact of tillage practices on organic carbon and nitrogen storage in cool, humid soils of eastern Canada. Soil and Tillage Research 41:191-201. https://doi.org/10.1016/S0167-1987(96)01100-2

Augusti, K. T. (1977): Hypocholesterolaemic effect of garlic (Allium sativum L.). Indian Journal of Experimental Biology 15(6): 489-490.

Aziz, I., Mahmood, T., Islam, K. R. (2013): Effect of long term no-till and conventional tillage practice on soil quality. Soil and Tillage Research 131:28-35. https://doi.org/ 10.1016/j.still.2013.03.002

Baghalian, K., Ziai, S. A., Naghavi, M. R., Naghdi, A. H., Khalighi, A. (2005): Evaluation of alliicin content and botanical traits in Iranian garlic (Allium sativum L) ecotypes. Scientia Horticulturae 103:155-166.

10.1016/j.scienta.2004.07.001

https://doi.org/

BBS. (2014): Monthly Statistically Bulletin, December-2014. Bangladesh Bureau of Statistics, Statistics Division, Ministry of Planning, Government of the People's Republic of Bangladesh.

De Vita, P., Di Paolo, E., Fecondo, G., Di Fonzo, N. Pisante, M. (2007): No-tillage and conventional tillage effects on durum wheat yield, grain quality and moisture content in southern Italy. Soil and Tillage Research 92(1-2): 69-78. https://doi.org/10.1016/j.still.2006.01.012

Derpsch, R., Friedrich, T., Kassam, A. Hongwen, L. (2010): Current status of adoption of no-till farming in the world and some of its main benefits. International Journal of Agricultural and Biological Engineering 3(1):1-25. doi: 10.3965/ j.issn.1934-6344.2010.01.0-0

Durak, I., Kavutcu, M., Aytac, B. (2004): Effects of garlic extract consumption on blood lipid and oxidant/antioxidant parameters in humans with high blood cholesterol. The Journal of Nutritional Biochemistry 15(6): 373-377. https://doi.org/10.1016/j.jnutbio.2004.01.005

Gomez, K. A., Gomez, A. A. (1984): Statistical Procedure for Agricultural Research. John Wiely and Sons. Inc. New York.

House, G.J., Parmelee, R.W. (1985). Comparison of soil arthropods and earthworms from conventional and no-tillage agroecosystems. Soil and Tillage Research 5(4):351360. https://doi.org/10.1016/S0167-1987(85)80003-9

Islah, M. H. (2010): Response of garlic (Allium sativum L.) to some sources of organic fertilizers under North Sinai conditions. Research Journal Agriculture and Biological Science 6(6):928936.

Islam, M. R., Uddin, M. K., Mian, M. A. K., Zaman, R., Hossain, J. (2015): Performance of garlic (Allium sativum L.) genotypes after transplant aman rice harvest under zero tillage mulched condition. International Journal of Applied Sciences and Biotechnology 3(1): 26-30. doi: 10.3126/ijasbt.v3i1.11216

Jamil, M., Munir, M., Qasim, M., Baloch, J., Rehman, K. (2005): Effect of different types of mulches and their duration on the growth and yield of garlic (Allium sativum L.). International Journal of Agriculture and Biology 7(4): 588-591.

Jones, M. G., Hughes, J., Tregova, A., Milne, J., Tomsett, A. B., Collin, H. A. (2004): Biosynthesis of the flavor precursors of onion and garlic. Journal of Experimental Botany 55(404):1903-1918. doi: 10.1093/jxb/erh138

Kabir, Z. (2005): Tillage or no-tillage:impact on mycorrhizae. Canadian Journal of Plant Science 85:23-29. https://doi.org/10.4141/P03-160

Kabir, M. A., Rahim, M. A., Taj, H. F. El., Majumder, D. A. N., Mahmood, S. (2011): Effects of tillage and different thicknesses of water hyacinth mulch on the growth and yield of garlic. Journal of Environmental Science and Natural Resources 4(2):19-26.

Kabir, M. A., Rahim, M. A., Majumder, D. A. N., Iqbal, T. M. T. (2013). Effect of mulching and tillage on yield and keeping quality of garlic (Allium sativum L.). Bangladesh Journal of Agricultural Research 38(1):115-125.

Karaye, A. K., Yakubu, A. I. (2006): Influence of intra-row spacing and mulching on weed growth and bulb yield of garlic (Allium sativum L.) in Sokoto, Nigeria. African Journal of Biotechnology 5 (3):260-264. doi:10.5897/AJB05.325

Kurian, J. C. (1995): Plant that Heal ( $1^{\text {st }}$ edn.) Oriental Watchman Publishing House, Punc., India. P.31

Pokhrel, A., Soni, P. (2018): An investigation into a resource and environmentally sustainable system: zero tillage lentil and garlic production in Nepal. Agroecology and Sustainable Food Systems 42(9):982-1002. doi.org/10.1080/21683565. 2018.1487359

Poldma, P., Merivee, A., Pae, A., Justus, K. (2005): Influence of planting time on the development, yield and quality of garlic. Acta Horticulturae 68(6): 333-338. doi: 10.17660/ActaHortic.2005.688.49

Puget, P., Lal, R. (2005): Soil organic carbon and nitrogen in a Mollisol in central Ohio as affected by tillage and land use. Soil and Tillage Research 80:201-213. doi.org/10.1016/ j.still.2004.03.018

Purseglove, J.W. (1975). Tropical Crops: Monocotyledons, ELBS Longman, London, pp. 52-56.

Rahim, M. A., Fordham, R. (1988): Effects of storage temperature on the initiation and development of garlic cloves (Allium sativum L.). Scientia Horticulturae 37 (1-2): 25-28. https://doi.org/10.1016/0304-4238(88)90148-3

Taucher, J., Hansel, A., Jordan, A., Lindinger, W. (1996): Analysis of compounds in human breath after ingestion of garlic 
using proton-transfer-reaction mass spectrometry. Journal of Agricultural and Food Chemistry 44(12):3778-3782. https://doi.org/10.1021/jf960640e

Triplett, Jr, G. B., Dick, W. A. (2008): No-tillage crop production: Arevolution in Agriculture. Agronomy Journal 100:153-165. https://doi.org/10.2134/agronj2007.0005c

Tucak, M., Cupic, T., Popovic, S., Stjepanovic, M., Gantner, R., Meglic, V. (2009): Agronomic evaluation and utilization of red clover (Trifolium pratense L.) germplasm. Notulae Botanicae Horti Agrobotanici Cluj-Napoca 37:206-210.

Wang, H., Li, X., Shen, D., Oiu, Y., Song, J. (2014): Diversity evaluation of morphological traits and allicin content in garlic (Allium sativum L.) from China. Euphytica 198: 243-254. 